\title{
Reseña del libro. Controversias en la historia de la ciencia y cultura científica
}

\author{
Autores. José Antonio Acevedo-Díaz y Antonio García-Carmona \\ Editorial: Los Libros de la Catarata \\ Lugar de edición: Madrid. España \\ Número de páginas: 112 \\ Año: mayo 2017 \\ ISBN. 978-84-9097-323-3
}

ÍNDICE

Prólogo, por Mariano Martín Gordillo

Preámbulo

Capítulo 1. La ciencia como parte de la cultura

Capítulo 2. Historia de la ciencia

Capítulo 3. Semmelweis y la fiebre puerperal

Capítulo 4. La controversia entre Pasteur y Pouchet sobre la generación espontánea

Capítulo 5. La controversia entre Pasteur y Liebig sobre la fermentación

Capítulo 6. Rosalind Franklin y la doble hélice del ADN

Capítulo 7. La controversia Tesla vs. Edison sobre las dos corrientes eléctricas - AC/DC Epílogo

Referencias bibliográficas

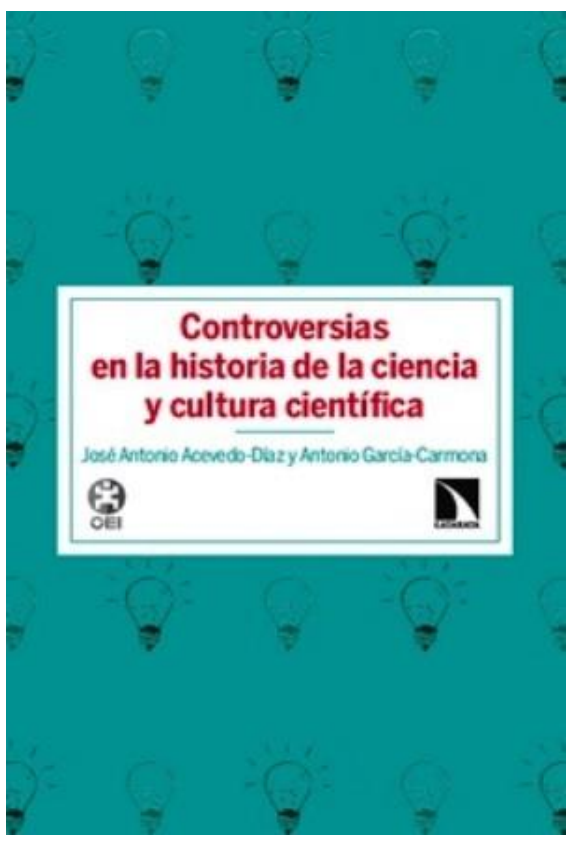

La idea de este libro surge ante la demanda de promover una cultura científica más adecuada y holística en la ciudadanía. Los autores defendemos que la adquisición de una cultura científica de este tipo permite a las personas interesarse y comprender mejor el mundo que las rodea; implicarse en discusiones en y sobre la ciencia; adoptar una actitud escéptica y cuestionadora; indagar para obtener conclusiones basadas en evidencias y tomar decisiones informadas respecto a asuntos como, por ejemplo, el medioambiente o su propia salud y bienestar. Los orígenes de una cultura científica así entendida están, sin duda, en la educación formal, pero deben continuar una vez finalizada esta.

Las controversias científicas son esenciales en la construcción del conocimiento científico porque impulsan el avance de la ciencia y muestran el conflicto como algo natural a la propia ciencia. Con las cuatro narraciones de controversias de historia de la ciencia que se presentan se pretende contribuir a que el lector se plantee y reflexione sobre diversos aspectos de lo que se suele denominar naturaleza de la ciencia; esto es, a su comprensión sobre cómo funciona la ciencia, y qué aspectos epistémicos y noepistémicos influyen en su desarrollo. Asimismo, la narración de la controversia de 
historia de la tecnología da algunas claves sobre la naturaleza de la tecnología, que se diferencia sustancialmente de la naturaleza de la ciencia.

Los personajes principales de las controversias científicas que se tratan en el libro son bastante conocidos en general: el húngaro Semmelweis, los franceses Pasteur y Pouchet, el alemán Leibniz, la inglesa Rosalind Franklin, el estadounidense Edison y el croata Tesla. Además de estos "actores principales" aparecen en ellas "actores secundarios", a menudo tan importantes los segundos como los primeros. No menos relevantes son los escenarios de las controversias, unas veces íntimos y públicos otras, pues también tienen un papel esencial en el desarrollo de estas. Asimismo, hemos procurado que en las narraciones no haya héroes ni villanos. Aunque el lector pueda tener más simpatía por unos personajes que por otros, estos se muestran -o al menos eso hemos pretendido- con sus virtudes y sus defectos, con sus éxitos y sus fracasos.

Concluiremos con unas palabras tomadas del prólogo del libro que ha escrito Mariano Martín Gordillo: "[los autores] han tenido el acierto de sintetizar de forma diáfana cinco episodios de la historia de la ciencia particularmente relevantes para entender su naturaleza. $Y$ han conseguido que el resultado sea tan atractivo para el lector curioso como útil para el docente en su aula. [...] Sin duda, este libro contribuye a demostrar que otra forma de entender la educación tecnocientífica es posible y necesaria."

Este libro pertenece a la serie Ensayos de Ciencia y Sociedad de la Organización de Estados Iberoamericanos para la Educación, la Ciencia y la Cultura (OEI), que es la entidad promotora: http://www.oei.es/historico/catarata.php. Ha sido editado por Los Libros de la Catarata: http://www.catarata.org/libro/mostrar/id/1251. Asimismo, cuenta con el apoyo de la Consejería de Economía y Conocimiento de la Junta de Andalucía.

Los autores

Referencia: Acevedo-Díaz, J. A. y García-Carmona, A. (2017). Controversias en la historia de la ciencia y cultura científica. Madrid: Los Libros de la Catarata

Contacto. ja.acevedodiaz@gmail.com,garcia-carmona@us.es 